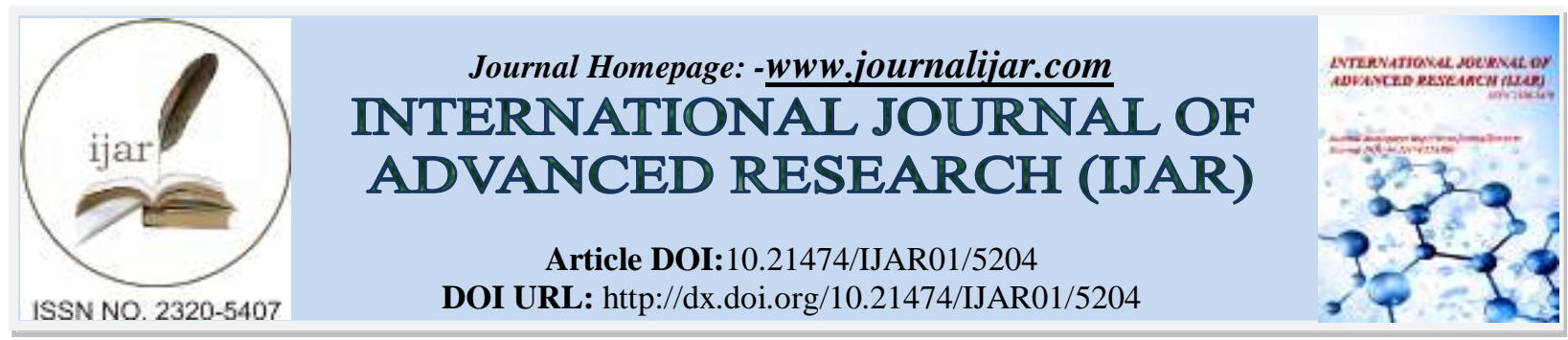

RESEARCH ARTICLE

\title{
PRELIMINARY PHYTOCHEMICAL SCREENING AND ANTIBACTERIAL ACTIVITY OF INDIAN MEDICINAL PLANTS AGAINST HUMAN PATHOGENS.
}

\author{
Margi H. Patel ${ }^{1}$ and Dr. Farida P. Minocheherhomji ${ }^{2}$. \\ 1. Research Scholar, Microbiology Department, B. P. Baria Science Institute, Navsari-396445, India. \\ 2. Associate Professor, Microbiology Department, B. P. Baria Science Institute, Navsari-396445, India.
}

\section{Manuscript Info}

Manuscript History

Received: 17 June 2017

Final Accepted: 19 July 2017

Published: August 2017

Key words:-

Antimicrobial activity, Medicinal plants,

Agar well diffusion method,

Phytochemical screening.

\begin{abstract}
Antibacterial efficiency of leaf extract of Flacourtia indica, Eujenia jambulaand Citrus sinensis were examined using Methanol as solvent and tested against the following five human pathogens: Staphylococcus aureus, Escherichia coli, Pseudomonas aeruginosa, Klebsiella pneumoniae and Salmonella typhi using agar well diffusion method. All the plants showed significant activity against the test pathogens except Klebsiella species. The methanolic extract of all three plants showed maximum zone of inhibition against Staphylococcus aureus and Salmonella typhi as compared to other organisms.
\end{abstract}

\section{Introduction:-}

Traditional herbal remedies are an important component for the provision of primary health care. They serve as an alternative to conventional medicines, which are normally too expensive. Historically, plants have provided a source of inspiration for novel drug compounds. Plant derived medicines have made large contribution to the overall human health and well-being.

In the present era, plant and herb resources which until a few decades were abundant, have now been found to be dwindling faster due to the onward march of civilization fast ${ }^{17}$. Plant extracts or bioactive herbal compounds have been evaluated for their biological activities. Phytochemicals are non-nutritive plant chemicals that have protective or disease preventive properties ${ }^{\mathbf{3}}$. Plants produce primary and secondary metabolites with divergent functions ${ }^{\mathbf{1 6}}$. The primary metabolites, amino acids, simple sugars, proteins and lipids are involved in cellular processes.

Secondary metabolites are chemically active compounds like flavonoids, alkaloids, terpenoids, steroids, saponins, which are produced in response to stress with complexity in structure and more restriction in distribution than the primary metabolites ${ }^{6}$. Plants can produce different kinds of secondary metabolites also known as natural products as they elicit effects on other organisms ${ }^{18}$.

Plants used for the study are briefly described below with their scientific name, common name, family. The present study was undertaken to analyze the antibacterial activity and phytochemical compounds of the Flacourtia indica, Eugenia jambula and Citrus sinensis extract.

\section{Plant Description:-}

1) Flacourtia indica:India. 
$>$ Family: Flacourtiaceae

$>$ Common name: Governor's pulm, Baichi or Katai and Madaraskarapulm.

$>$ Uses: It is a native of tropical Asia and Africa. This plant has been reported as an effective remedy for the treatment of a variety of diseases. Leaves are used in treatment of inflammation, jaundice and as blood purifier ${ }^{7}$. Although different parts (leaves, bark, stem, fruits, root and even whole plant) of the Flacourtia indica have been demonstrated for several pharmacological activities ${ }^{8}$.

2) Eujenia jambula (Syzygium cumini):-

$>$ Family: Myrtaceae

$>$ Common name: Java pulm and Malabar pulm

$>$ Uses: it is a native to the Indian subcontinent and adjoining regions of South-East Asia. Leaves are used for controlling blood pressure and gingivitis ${ }^{\mathbf{1 2}}$.

3) Citrus sinensis (Citrus aurantium):-

$>$ Family: Rutaceae

$>$ Common name: Sweet orange

$>$ Uses: Orange trees are widely cultivated in tropical and subtropical climates for its tasty juice and medicinal value $^{13}$. Orange peel extract possess many medicinal properties. It is used to treat and prevent vitamin deficiencies, colds, flu and scurvy and helping to fight viral and bacterial infections ${ }^{4}$.

\section{Materials and Methods:-}

2.1 Collection of Plants:-

The present work was carried out at Department of Microbiology, B. P. Baria Science Institute, Navsari, Gujarat, India. All the plants: Flacourtia indica, Eujenia jambula and Citrus sinensis were collected from the Botanical Garden of Navsari Agriculture University (N.A.U.), Navsari. Their botanical identification and authentication was done by the authorities of the Herbarium of N.A.U. The leaves of these plants were thoroughly washed with water and dried under shade for about ten days. The dried plant samples were ground well into fine powder in a mixture grinder. The powders were stored in air sealed polyethylene bag at room temperature before extraction ${ }^{10}$.

\subsection{Organic Solvent Extraction:-}

$10 \mathrm{gm}$ of powder was mixed with $100 \mathrm{ml}$ organic solvent (methanol). The mixture was incubated for 48-72 hours on rotary shaker. Mixture was filtered using Whatmann filter paper no.1 and evaporated under hot air oven to yield the powder form of pure extract. Stock solutions of crude extracts were prepared by mixing organic solvent with appropriate amount of dried extracts to obtain a final concentration of $100 \mathrm{mg} / \mathrm{ml}$. The solvent used was $20 \%$ DMSO. The filtrates were collected and stored at $4{ }^{\circ} \mathrm{C}$ for further experiment.

\subsection{Microbial Cultures:-}

The bacterial cultures for the present study were procured from NCIM, Pune, India. They included both Gram positive and Gram negative bacterial strains,

$>$ Staphylococcus aureus (NCIM 2079)

$>$ Escherichia coli (NCIM 2065)

$>$ Pseudomonas aeruginosa (NCIM 2863)

$>$ Salmonella typhi (NCIM 2501)

$>$ Klebsiella pneumonia (NCIM 2883)

These bacterial cultures were grown on Nutrient Agar (NA) plates at $37{ }^{\circ} \mathrm{C}$. Then the stock cultures were then preserved for further studies.

\subsection{Antimicrobial Activity:-}

Organic extracts of Flacourtia indica, Eujenia jambula and Citrus sinensis extracts were subjected to antibacterial activities by in vitro agar well diffusion method. Autoclaved Muller Hilton (MH) agar was plated and seeded with $100 \mu 1$ of the inoculums concentration and spread on the solid agar plates. Using sterile cork borer, $6 \mathrm{~mm}$ diameter was made on the agar media. $100 \mu \mathrm{l}$ of each plant leaves extract was filled in the respective wells and the plates were incubated at $37^{\circ} \mathrm{C}$ for 18 hours. The diameter of zone of inhibition was measured in $\mathrm{mm}$ as per the Kirby Bauer technique ${ }^{1}$. 


\section{Qualitative Phytochemical Screening:-}

Phytochemical investigation of the leaves extracts were carried out to confirm the presence of secondary metabolites for alkaloids, carbohydrates, proteins and amino acids, steroids, phenolic compounds and tannins and flavonoids by using standard protocols ${ }^{11}$.

$>$ Alkaloids: $1 \mathrm{ml}$ of the filtrate on mixing with $2 \mathrm{ml}$ of Drangendroff's reagent shows a development of turbid orange colour.

$>$ Tannins: $1 \mathrm{ml}$ of the filtrate on mixing with $2 \mathrm{ml}$ of Ferric chloride promotes development of dark green colour.

$>$ Saponins: $1 \mathrm{ml}$ of the filtrate is added to $2 \mathrm{ml}$ of distilled water and shaken vigorously. It is then allowed to stand for 10 minutes. Foam formation on the top layer of the mixture, which remains for 9 to 11 minutes, is an indication of the presence of saponins.

$>$ Anthraquinones: $1 \mathrm{ml}$ of the filtrate is mixed with $10 \mathrm{ml}$ of benzene and is then filtered. $5 \mathrm{ml}$ of $10 \%$ ammonia is then added to the above filtrate and shaken vigorously. Development of pink tone in the solution indicates the presence of Anthraquinones.

$>$ Anthocyanides: $1 \mathrm{ml}$ of the filtrate when mixed with $5 \mathrm{ml}$ of dilute HCL gives pale pink tone.

$>$ Phenolic flavonoids: $1 \mathrm{ml}$ of the filtrate mixed with $2 \mathrm{ml}$ of $10 \%$ lead acetate leads to formation of brown precipitates.

Flavonoids: $1 \mathrm{ml}$ of the filtrate on mixing with $2 \mathrm{ml}$ of dilute sodium hydroxide shows the development of golden yellow tone.

$>$ Carbohydrates: Addition of a 2-3 drops of Molisch's reagent and 2-3 drops of concentrated $\mathrm{H}_{2} \mathrm{SO}_{4}$ to $1 \mathrm{ml}$ of the filtrate gives a purple colour.

$>$ Proteins: $1 \mathrm{ml}$ of filtrate on mixing with concentrated nitric acid gives yellow colour indicates the presence of proteins.

$>$ Steroids: $1 \mathrm{ml}$ of chloroform and $1 \mathrm{ml}$ of $\mathrm{H}_{2} \mathrm{SO}_{4}$ are added slowly by the sides of the test tube containing $1 \mathrm{ml}$ of the filtrate. If upper layer turns red in tone and the sulphuric acid layer exhibits a greenish yellow fluorescence, then steroids are present.

$>$ Terpenoids: Addition of $2 \mathrm{ml}$ chloroform and 2-3 drops of concentrated sulphuric acid carefully to $1 \mathrm{ml}$ of the filtrate leads to the development of reddish brown colour at the interface.

$>$ Phlobatannins: Addition of few drops of $1 \%$ HCL to $1 \mathrm{ml}$ of the filtrate leads to the formation of red precipitates.

$>$ Cardiac Glycosides: $2 \mathrm{ml}$ of the extract was dissolved with $2 \mathrm{ml}$ of chloroform and conc. $\mathrm{H}_{2} \mathrm{SO}_{4}$ was added and cooled. Formation of brownish green colour indicated the presence of cardiac glycosides.

\section{Results and Discussion:-}

\subsection{Antibacterial Assay:-}

The antibacterial activity of methanolic extracts of Flacourtia indica, Eujenia jambula and Citrus sinensis were tested against human pathogenic bacteria by agar well diffusion method.

$>$ Of the five test bacteria, Staphylococcus aureus and Salmonella typhi were found to be sensitive to methanolic extract of Eujenia jambula, producing wide inhibition zone of $13 \pm 0.2$ and $11 \pm 0.1$ respectively.

$>$ Further Staphylococcus aureus $(12 \pm 0.1)$ and Salmonella typhi $(12 \pm 0.2)$ exhibited greater sensitivity to methanolic extract of Citrus sinensis.

$>$ Staphylococcus aureus and Salmonella typhi shows average sensitivity to methanolic extract of Flacourtia indica as compared to other human pathogens such as Escherichia coli, Pseudomonas aeruginosa and Klebsiella pneumoniae.

Therefore Staphylococcus aureus, Salmonella typhi, Escherichia coli and Psuedomonas aeruginosa showed better antibacterial activity except Klebsiella species as shown in Table-1 and Graph-1.

The results obtained are congruent with the work of other researchers ${ }^{5}$, who had evaluated the antibacterial activity of Cassia fistula and Flacourtia indica on both Gram positive and Gram negative bacteria at varying concentrations. Also, organic solvents such as methanol, ethanol and acetone extracts of Eujenia jambula seeds have significant antimicrobial activity against human pathogens ${ }^{2}$. The ethanolic extract of Citrus sinensis showed excellent inhibitory action against Escherichia coli and Klebsiella pneumoniae ${ }^{\mathbf{1 4}, 15}$. 
Table-1:- Antibacterial activity of methanolic extract of Flacourtia indica, Eujenia jambula and Citrus sinensis against human pathogens.

\begin{tabular}{|l|c|c|c|}
\hline \multirow{2}{*}{ Microbial Strains } & \multicolumn{3}{|c|}{ Zone of Inhibition, in mm } \\
\cline { 2 - 4 } & Flacourtia indica & Eujenia jambula & Citrus sinensis \\
\hline Staphylococcus aureus & 11 & 13 & 12 \\
\hline Salmonella typhi & 10 & 11 & 12 \\
\hline Escherichia coli & 8 & 9 & 7 \\
\hline Pseudomonas aeruginosa & 9 & 9 & 8 \\
\hline Klebsiella pneumonia & - & - & - \\
\hline
\end{tabular}

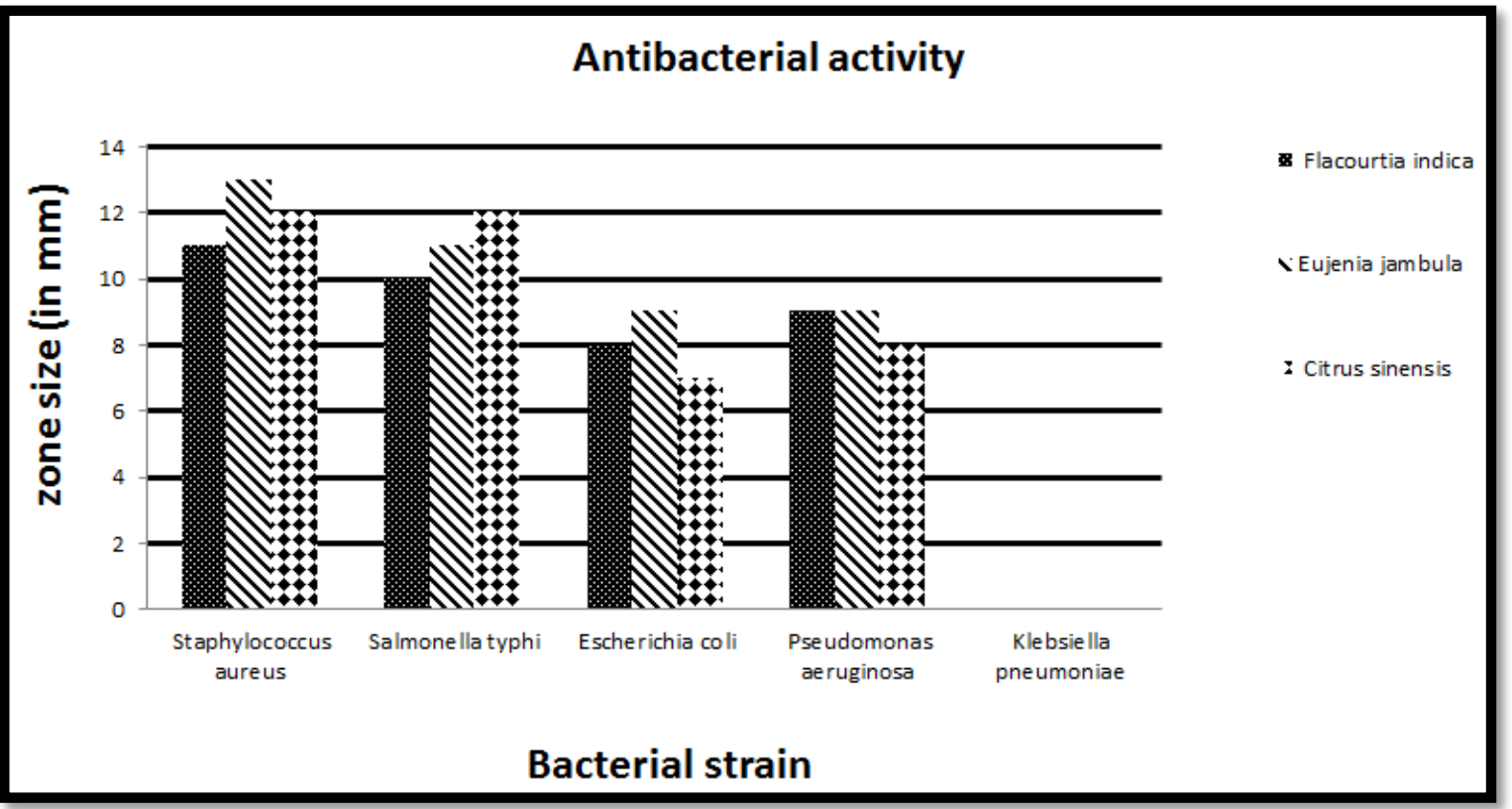

Graph-1:- Antibacterial activity of methanolic extract of Flacourtia indica, Eujenia jambula and Citrus sinensis

Phytochemical Screening:against human pathogens.

Phytochemical analysis of methanolic extract of all three selected plants indicated high in vitro potential for antibacterial activity to varying degrees against all bacterial pathogens tested. The results of phytochemical tests indicated presence of secondary metabolites in leaves extract of Flacourtia indica, Eujenia jambula and Citrus sinensis extract as listed in Table-2.

Table-2:- Qualitative phytochemical analysis of methanolic extract of Flacourtia indica, Eujenia jambula and Citrus sinensis

\begin{tabular}{|l|l|c|c|c|}
\hline \multirow{2}{*}{ Sr. \# } & \multicolumn{2}{|c|}{ Phyto Constituents } & \multicolumn{2}{c|}{ Results } \\
\cline { 3 - 5 } & & Flacourtia indica & Eujenia jambula & Citrus sinensis \\
\hline 1 & Alkaloids & + & - & + \\
\hline 2 & Tannins & + & + & - \\
\hline 3 & Saponins & + & + & - \\
\hline 4 & Anthraquinones & - & - & - \\
\hline 5 & Anthocyanides & + & - & - \\
\hline 6 & Phenollic flavonoids & + & + & - \\
\hline 7 & Flavonoids & + & + & - \\
\hline 8 & Carbohydrates & - & - & - \\
\hline 9 & Proteins & + & + & + \\
\hline 10 & Steroids & + & + & - \\
\hline
\end{tabular}




\begin{tabular}{|l|l|c|c|c|}
\hline 11 & Terpenoids & + & ++ & - \\
\hline 12 & Cardiac Glycosides & - & - & - \\
\hline 13 & Phobatannins & - & - & - \\
\hline
\end{tabular}

Signages: (+) indicates presence of constituent; (-) indicates absence of constituent

\section{Conclusion:-}

The indiscriminate use of antibiotics has led to the development of many resistant microorganisms creating immense clinical problems in the treatment of infectious diseases such as those caused by multi drug resistant species of human pathogens. Therefore, there is a need to develop alternative antimicrobial agents for the treatment of these infectious diseases. In modern medicines, a non-antibiotic approach includes the application of the potential of higher plants as source of new antimicrobial agents. There are many reports available for the antimicrobial, antiviral and antifungal properties of plants ${ }^{9}$.

Based on the results described, we may conclude that methanolic extracts of Flacourtia indica, Eujenia jambula and Citrus sinensis extract have significant antimicrobial activities against Staphylococcus aureus, Salmonella typhi, Escherichia coli and Pseudomonas aeruginosa. It is possible to find the better therapies for many microbial diseases from the plants. Now a days, nanotechnology gains ground due to its small particle size and high surface area in every profession mainly in medical technology. Further metallic nanoparticles can be synthesized from the herbal extracts of Flacourtia indica, Eujenia jambula and Citrus sinensis which would be helpful in the prevention and treatment of microbial diseases.

\section{Acknowledgement:-}

The authors would like to thank the Authorities of Navsari Agriculture University, Navsari, Gujarat, and Dr. Bimal Desai, Assistant Professor (Basic Sciences), Botany Department, ASPEE College of Horticulture \& Forestry, NAU, for providing all assistance in identification and authentication of the medicinal plants used in this study.

\section{Bibliography:-}

1. Bauer AW et al. (1966); Antibiotic susceptibility testing by standardize single disc or cup method; Amer. J. Clini. Path., 45(4): 493-496.

2. Denis O, Eliakim M, Godfrey M, David K, Geoffrey O (2015); Antimicrobial activity of Eugenia jambulana seeds against footborne isolates; Journal of Scientific \&Innovative Research, 4(6): 232-236.

3. Gayathri D, Eramma N (2013); Antibacterial potential and phytochemical analysis of Flacourtiaindica (Burm.f.) Merr. root extract against human pathogens; Indo American Journal of Pharmaceutical Research, 3(5): 38323846.

4. Grosso G, Galvano F, Mistretta A, Marventano S, Nolfo F, Calabrese (2013); G. Red orange: experimental models and epidemiological evidence of its benefits on human health; Oxid Med Cell Longev. 2013:157240.

5. Hajra S, Mehta A, Pandey P (2011); Assessment of antimicrobial activity of Cassia fistula and Flacourtiaindica leaves; J Pharm Res., 4(7): 2432-2435.

6. Keeling C, Bohlmann J (2006); Genes, enzymes, and chemicals of terpenoid diversity in the constitutive and induced defence of conifers against insects and pathogens; New Phytologist; 170:657-675.

7. Kirtikar K, Basu B (1933); Indian medicinal plants. New Delhi: Bishen Singh Mahendra Pal Singh, 1(2): 220222.

8. Kota G, Karthikeyan M, Kannan M (2012); Flacourtiaindica (Burm. f.) Merr.-A. Phytopharmacological Review; Int. J Res Pharmaceut Biomed Sci., 3(1), 78-81.

9. Lachumy S, Sreenivasan S, Vello S, Zakaria Z (2010); Pharmacological activity, phytochemical analysis and toxicity of methanol extract of Etlingeraelatior (torch ginger) flowers; Asian Pacific Journal of Tropical Medicine. 3(10): 769-774.

10. Mamta K, Sulbha L, Prabhakar V, Sudhir R, Suresh R, Shailendra G (2011); Anti-Inflammatory and Antimicrobial activity of FlacourtiaRamontchi Leaves; International Journal of Drug Development \& Research. 3(2): 308-313.

11. Minocheherhomji FP, Vyas BM (2014); Presence of Alkaloids in medicinal plants and their importance in antimicrobial activities on some pathogenic microbial strains; Journal of Environmental Research \& Development, 9(1): 144-150.

12. Ram P, Seamy V, Suranjit P, Ajit V (2012); Biogenic synthesis of silver nanoparticles from the leaf extract of Syzygiumcumini (L.).; International journal of pharma and biosciences. 3(4): 745-752. 
13. Shakthi A, Sathish T, Kumaresan K, Rapheal V (2014); Extraction process optimization of polyphenols from Indian Citrus sinensis - as novel antiglycative agents in the management of diabetes mellitus; J Diabetes MetabDisord. 13:11.

14. Suja D, Bupesh G, Nivya R, Mohan V, Ramasamy P, Muthiah N, Arul A, Meenakumari K, Prabu K (2017); Phytochemical Screening, Antioxidant, Antibacterial Activities of Citrus Limon and Citrus Sinensis Peel Extracts; International Journal of Pharmacognosy and Chinese Medicine. 1(2): 1-7.

15. Vennila S, Bupesh G, Mathiyazhagan K, Basker M, Amutha S (2012); Qualitative phytochemical Screening and Invitro antioxidant activity of H.isora.; Adv Biotech J 14: 3-20.

16. Visweswari G, Rita C, Rajendra W (2013); Phytochemical screening of active secondary metabolites present in WithaniaSomnifera root: role in traditional medicine; International journal of pharmaceutical sciences and research. 4(7): 2770-2776.

17. Vogel H (1991); Similarities between various systems of traditional medicine. Considerations for the future of ethnopharmacology; J. Ethnopharma col. 35: 179-190.

18. Zwenger S, Basu C (2008); Plant terpenoids: applications and potentials; Biotechnology and Molecular Biology Reviews. 3:001-007. 